Freak Scene: Cinema-going Memories and the British Counterculture of the 1960s.

Dr Patrick Glen

University College London (now the University of Wolverhampton)

p.glen@wlv.ac.uk or pmjglen@gmail.com

Keywords: counterculture, British history, cinema, cinema-going, oral history

Article length: 9633 words

Funding details: This work was supported by the Arts and Humanities Research Council as part of Cultural Memory and British Cinema-going of the 1960 s project.

Biographical note: Patrick is a Research Fellow in History at the University of Wolverhampton. He is an expert in the social and cultural history of post-War Britain, popular music, the press, audience research and discussions of social mores. He is the author of Youth and Permissive Social Change in British Music Papers, 1967-1983. At the time of researching this paper he worked at University College London as the Postdoctoral Research Associate on the AHRC-funded projects 'Cinema-going and Cultural Memory of British Cinema-going' and 'Remembering 1960s British Cinema-going'.

Video abstract: to follow.

\begin{abstract}
Using oral history interviews and questionnaires gathered as part of the 'Cultural Memory and British Cinema-going of the 1960s' project, this article recovers and analyses the reminiscences of people who were interested or involved in the British counterculture. By drawing on a broader range of experiences than typically represented in canonical accounts of the counterculture and those that have informed prior historical scholarship, it adds a wider range of experiences, understandings and behaviours when considering how people remember their discovery of the counterculture and its bearing on their social lives, understanding of film, popular culture, politics and society. The article demonstrates how film and, more generally, popular culture held significance in presenting ideas about counterculture as well as how cinemas and film clubs provided spaces for people to socialise and develop subcultural networks. It also suggests how significant class, locality, educational experiences and gender were in shaping how people did or did not enter countercultural scenes, how they understood themselves, their cinema-going experiences and the films that they watched.
\end{abstract}




\section{Freak Scene: Cinema-going Memories and the British Counterculture of the 1960s.}

\section{Dr Patrick Glen}

Oscar: It would be one night, we could only get away with one night and that would be the late night screenings. Erm... the only people who were up late at night were the freaks - it was great.

Interviewer: Yeah. So how many people would turn up for these showings?

Oscar: Erm... I'm tempted to say hundreds but it was more like dozens. I do remember completely full cinemas. The Odeon had a seating of two thousand and so maybe two thousand.

Interviewer: They did late night showings there?

Oscar: Yeah. Erm... I did go to late night showings there but something like 2001(: A Space Odyssey [1967]) - a bit more mainstream. The freaky Italian horror movies and stuff would probably be about 200 people.

Interviewer: Yeah. How did people's behaviour at these types of films differ from the more mainstream...

Oscar: Well, considering that most people were absolutely stoned, they were quite quiet [laughs].

Interviewer: Did they smoke joints in the cinema?

Oscar: Yeah, yeah, you could smoke in cinemas and there was an absolute fug so you could, very quickly, sneak a joint in. Acid would be taken beforehand which would always make the horror films interesting.

The Odeon Cinema on Oxford Road in the centre of Manchester was demolished last year leaving space for a multi-storey car park and an opportunity for Mancunians to lament their City Council's attitude to heritage and cultural memory that is secondary to their will to attract 'luxury developments'. Still, the Odeon remains - remembered from different angles, distorted through the prisms of personal memory and the ways those memories are articulated - in the recollections of generations of visitors from the city, its suburbs and the North West. When Oscar was a child his parents would take him to the Odeon - that he would later frequent wide-eyed under the influence of LSD and the luminescent glow of a Mario Bava horror film - for family outings. His parents also took him on outings to other now lost cinemas: Cine City in Withington (replaced by flats) or the Northenden Forum (or as of 1964, the ABC Wythenshawe) on Palatine Road (now a Jehovah's Witness Assembly Hall). Similar family outings were common in Britain from the dawn of cinemagoing in the 1900s up to and beyond the decline in cinema-going and cinema closures of the 1960s. As cinemas began to shut down during the 1960s, however, and as Oscar points out, there was an opportunity for cinemas to survive by satisfying certain niches. In some, at certain times, out went the families and in came the 'freaks.'

These 'freak' scenes or hubs of countercultural activity could be found in cinemas like the Odeon, but they were also frequently found in improvised settings such as basements or university 
halls in towns and cities across Britain. Within these cinema spaces, social groups with shared (or at least complimentary) mores, political inclinations, cultural interests and social lives gathered and organised to create and renegotiate what it meant to be involved in the counterculture. As Oscar's account hints, people commonly remember how the countercultural groups were often very small, how they frequently evaded the patterns of life that most people adhered to (staying up late at night) and shared specific cultural reference points (Italian horror, for instance). Almost invariably, people within countercultural milieu often shared an active interest in psychoactive substances. This article uses memories of cinema-going from Oscar and other like-minded people as a means to recover and analyse how some people entered into countercultural scenes through (in some part) the cinema but also determined by several social and cultural factors. It considers what they remember in these cinema spaces and how this affected their understanding of films. Images of the counterculture have a significant hold over our histories and understandings of the 1960s. This article introduces voices from beyond the usual countercultural voices to develop our grasp of these scenes and their relationship to cinema-going and British society.

\section{Introduction}

In an earlier article (published in Media History), I outlined the discrepancies between the press's reports of young people going to the cinema during the 1960s and how those who were young at the time recalled their experiences. ${ }^{. i}$ The findings were based upon the AHRC-funded Cultural Memory and British Cinema-going of the 1960s project's findings, a collection of transcripts and recordings of between 900 and 1000 discussing their memories of their lives and going to the cinema in the 1960s. I argued that the participants typically stressed community and recollections of escapism from lives which people remember as, generally, less exciting than the lifestyles suggested by media portrayals or other sources that inform our notions of the mythological decade of the 1960s. Indeed, fewer cinema-goers appear to have been involved or interested in the counterculture than might be imagined from popular myths. Our research established, however, that some young people did live or, at least, try to live lives that strayed from the supposed norms of 1960s British society in ways they believed to be countercultural.

In general, we found evidence of a dynamic 1960s in which changing ideas, lifestyles and opportunities were contingent on factors such as class, locality, gender, race and sexuality: access to new lifestyles, freedoms and material improvements were contingent and reversible. Within this society in which rapid changes could be experienced and felt but certain cultures and continuities remained in some ways resilient to change; for instance, it took specific freedoms to 'swing' or be countercultural. Our respondents predominantly narrated experiences of family, community and work intertwined with cinema-going as a means of escape and voyeuristic pleasures from a society that is often remembered as grey and dull compared to the technicolour offerings on screen. In working class urban areas, for instance, the cinema was a vital element of community life into the 1960s: there are accounts of cinemas near the docks and shipyards of Liverpool and Glasgow which privilege, rather than memories of films, memories of characters in the audience, group interactions and amusing quips shouted across the auditorium. These memories reinforce ideas of working class identity and the power of communal interactions; these encounters might not have been at the cutting edge of counterculture or social change but articulate understandings of particular modes of leisure, resistance to certain social mores and figures of authority. The memories recited are certainly not deferential as the remembered politics of standing for the British national anthem bear 
testament (some stood but others certainly did not), yet they do often evoke similar imagery to Annette Kuhn's work on cinema-going during the 1930s. iii The typical observation recited in memories of the 1960s drawn from our survey is, however, encapsulated by Mervyn from Birmingham who wrote:

I lived in a working-class neighbourhood which meant that the films I liked were escapist. Life was humdrum and with little opportunity, it seemed to me, for travel or any kind of new experience. ${ }^{\text {iv }}$

Three respondents made nearly identical claims (men and women from Nottingham, Durham and Kent) and the general sentiment shared by a significant proportion of our respondents when asked to reflect on the relationship between their cinema viewing and personal experience of the 1960s.

Some people, however, could access new ideas and experiences that were countercultural or at the sharp edge of social changes and that cinema-going and cinema was remembered an significant aspect of journey into this subculture or social niche. This article uncovers a different angle, therefore, to the project's prior work. While conceding that those who were interested or involved in the counterculture were relatively few (in our sample at least), it uses what we have to develop and explanation of cinema-going's affective relationship with the counterculture or countercultures. Many of the people who were involved in the counterculture were relatively young - teens or in their twenties during the 1960s - which reinforces Victor Burgin's psychoanalytic approach to the affective relationship between cinema-going and young people. ${ }^{v}$ He argued that, at the cinema, the viewer could take cues from images and messages that profoundly affect how they imagine and conduct themselves. This development of a self is distinct from cues takes from family or education. Cinema-going can, therefore, be a crucible for individual and collective change. Indeed cinemas have been described as Foucaludian heterotopia where cinema-goers could deviate from social norms in a space where they were exposed to non-normative approaches to time and

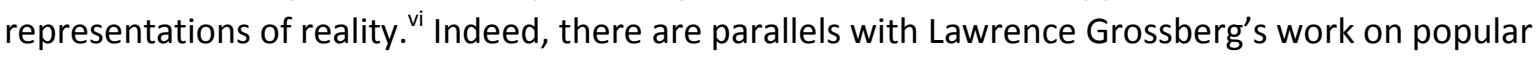
music subcultures in terms popular culture of providing means to create 'maps' of mutual understanding and affiliation. ${ }^{\text {vii }}$ Cinema provided a place where social groups could congregate, experiences certain messages and images then respond to them socially.

Using the oral history interviews and questionnaires gathered by the project, this article recovers and analyses how counterculture participants, through cinema-going and other aspects of life that they mentioned, found and created cinema spaces to congregate, socialise and to explore the alternative messages that could be taken from films. I consider how these people became at least temporarily 'countercultural'; how they understood the counterculture; how they interacted (or not) with others who shared similar social or subcultural identities; and how cinema-going and certain films played a role in this. Within the cinema, people who were so inclined could find countercultural messages in films, use the cinema as a place to socialise with those who had similar interests, or even develop their own cinema spaces, films and distribution network of alternative cinema. Interrogating these perspectives contributes to increasing the range of countercultural voices from the usual scenes of metropolitan tastemakers to take in a broader national impression. It also develops knowledge of how class, educational opportunities and encouragement, often parental, to explore film, arts and culture, broadly what Bourdieu termed 'cultural capital', profoundly affected the way in which people in our became adherents of the counterculture, understood and remembered their engagement with it. ${ }^{\text {viii }}$

Accounts of the British counterculture in the 1960s are dominated by those who 'were there' and maintained a sufficient public profile to write books, appear on documentaries, television 
shows or radio broadcasts. Jonathan Green's history of the 1960s counterculture, in which he was also a participant, for instance, describes the 'underground' as not 'clandestine nor revolutionary' and distinct from the 'Swinging London' of 'magazine writer's fantasies or a caravan-borne procession of paisley-wearing aristos. ${ }^{\text {ix }}$ Instead, he describes the counterculture as the 'alienated children of the comfortable bourgeoisie' who were elitist, scornful of both left and right, in favour of liberal social reform and in control of their own media - including film. Green's perspective is broadly in line with a number of fellow participants' accounts. ${ }^{x}$ Colin Campbell who also sees the 1960s as a 'revolutionary' decade provides an analysis that is broadly in line with Green's account but concludes that the young middle-class and anti-materialist underground was 'destined...to bring dramatic changes to the civilization of the West. ${ }^{\text {xi }}$ While there is some credence to the social and intellectual characteristics of the counterculture as outlined in the above analyses, particularly in terms of class, it is also clear, that they contribute to overstatements regarding its socio-cultural impact and focus almost entirely on a London-oriented aspect of the counterculture. This article problematise these ideas of counterculture by drawing from a different constituency of participants in the underground - most were from the provinces and only one might merit a mention in histories of core counterculture participants. Yet, unlike Sharif Gemie and Brian Ireland's work on 'beatniks' and 'hippies', it will be argued here that the people encountered in our survey, if not the most 'sophisticated' or connected members of the metropolitan or international counterculture, did understand themselves as being part of the counterculture - to them their subcultural affiliation had 'real social validity.' ${ }^{\text {xii }}$

Some historians have taken a more sober and nuanced view concerning the counterculture's social and cultural impact. Several scholars, such as Adrian Bingham, argue that the overstatement of the counterculture cultural power is an aspect of the media myths of the 1960s. ${ }^{\text {xii }}$ Yet, those who do so, Mark Donnelley, for instance, accept that the countercultural created a place for people to discuss and try to articulate and live out ideas of free expression, social equality and tolerance, improve the environment, and create alternative public spaces. ${ }^{\text {xiv }}$ There have, however, been a number of analyses that suggest how the British counterculture was a predominantly white, middleclass, male-dominated culture that was largely located in London. Indeed, some historians including Andrew August, Rosalind Brunt, Beatrix Campbell, Shelia Rowbotham and Shelia Jeffreys have argued that the counterculture was less radical, neither liberal nor enlightened, but rather a setting in which male sexual privilege and sexism loomed large. ${ }^{\mathrm{xv}}$ Michel Foucault agreed the counterculture and the social upheaval promised much but the openness it promised was partial and many aspects of social liberation were restricted or simply not topics of discussion. ${ }^{\text {xvi }}$ As implied in the participant accounts for the 'Cultural Memory and British Cinema-going of the 1960s' survey, class was also a significant barrier to entering the counterculture therefore limiting its potential impact: countercultural cinema-goers are quite different to members of the working class subcultures identified by the Birmingham School of Cultural Studies or, more recently, Keith Gildart's work on the working class and popular music. ${ }^{\text {xvi }}$ Still, they understand themselves using categories to self-define as members of a subculture or to explain how they interacted with subcultural ideas, fashions, cultural products, fashions and social groups. By moving the aim of analysis away from the media savvy metropolitan subcultures alone, we can see how, through the prism of the cinema as an alternative public space, the counterculture is remembered as affecting people differently - often shaped by their personal circumstances, locality, backgrounds and social identity. Such a reorientation sheds light on the enduring perceptions of the counterculture when considering people's understanding of themselves, their lives in the 1960s and the 1960s in Britain more generally. 
This article uses methods pioneered in New Cinema History. New Cinema History itself endeavours to recover and explain the social basis of cinema-going and film reception but also suggests general ways in which popular culture interacts with everyday lives and society. As Richard Maltby has explained this is distinct from film history - studies concerned with the production,

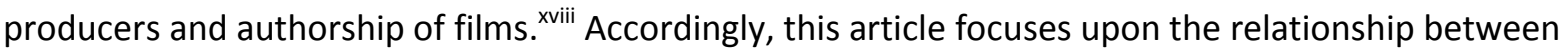
a subculture (or set of related subcultures, the counterculture), cinema-going and society using semi-structured oral history interviews and questionnaires. It builds upon existing scholarship that used encounters with cinemas to recover the social and cultural history of a certain audience (and specifically of the British experience following Annette Kuhn and Sarah Smith's work on the 1930s, Nirmal Puwar's explorations of post-war social cinema spaces, and the work on the 1960s by Melvyn Stokes, Emma Pett and Matthew Jones). ${ }^{\text {xix }}$ And does so with the understanding that 'cinemas are sites of social and cultural [that have] as much to do with patterns of employment, urban development, transports systems and leisure practices' as individuals' encounters with individual films (Victor Burgin has also noted how difficult it is to decipher individual's memories of films as they are fragmented, partial and idiosyncratic). ${ }^{\mathrm{xx}}$

The responses to the Cultural Memory and British Cinema-going of the 1960s survey were a self-selecting snowball sample, but efforts were made to reach as representative a sample as possible in terms of gender, race, sexuality, age and region. We collected nearly 1,000 questionnaires and 80 interviews. This article focuses on people who understood themselves as part of or interested in the counterculture and, as a result, only a small number (seven) of respondents had relevant engagement with countercultures. This also affected the diversity of the sample, the respondents featured are all white British, predominantly middle class or socially mobile, and all but one was heterosexual. This could prove a methodological problem, however, there is a growing precedent for studies based upon small samples to recover memories and histories of groups that were not rigorously documented at the time or, in the case of the counterculture, were recorded with a particular slant by cultural gatekeepers at the centre of the milieu. Florence SutcliffeBraithwaite's study of young women, gender and sexuality on the Isle of Sheppey in 1980, for instance, used a single oral history transcript - an interview with 'Sue' - to uncover insights into women's sexual subcultures in Kent ports and make broader conclusions about gender expectations British society. ${ }^{\times x i}$ She explained, 'how historians can use a single individual's narrative to offer a broader account of British culture and of subcultures, by starting with the individual and examining how they subjectively interacted with broader cultural discourses. ${ }^{. x \times i i}$ This article has made similar use of a small sample. Their transcripts and questionnaires, as Annette Kuhn advocates in her influential oral history investigation of British cinema-going during the 1930s, have been interrogated using an ethnohistorical approach - reminiscences are, therefore, considered as memory texts to decode and analyse. xxiii

\section{Becoming Countercultural}

Seven of our participants understood their time during the 1960s as having some sort of sustained encounter with the counterculture either as participants who moved within a countercultural milieu or as avid followers of countercultural ideas, media and fashions. All but two of this group were middle class throughout their lives, the other two having come from working class but attended university and subsequently worked middle-class jobs. Five of the seven are men and two are women, all are white and British, the oldest being born in 1942 and the youngest in 1951. Six of the 
seven are heterosexual and one is a gay man. All came from various locations across England and many subsequently moved to study and work. Their memories contain distinct similarities but also differences. For most of the seven interviewed, certain films are remembered as resonating with them in a way that made them seek alternatives to the ideas and society they had inherited from prior generations. It is also notable, however, how understandings and realities of class, family, locality and educational experiences seem to have a profound effect on the way people narrate their entry into the countercultural scene.

Some respondents to our interviews and questionnaires remember certain films fondly because they have come to remember them as triggering an immediate reaction that changed their perception of who they were, what they wanted to be and the time that they lived in. Joel was born in 1947 in Leeds where he lived until the late-1960s when he went to Plymouth College of Art. ${ }^{\text {xiv }} \mathrm{He}$ remembered Michelangelo Antonioni's film about a young London-based photographer embroiled in a dangerous mystery, Blow Up! (1966) as his most poignant memory of visiting the cinema during the 1960s. It was a film that, in part, contributed to the myth of 'swinging London' and Joel described it as having 'a powerful effect on [his] adolescence at the time.' This narrative sets up his decision to pursue art as a profession and his discussion of how subsequently he 'related to [the] hippy/swinging London ethos' adding 'seen as the same rather than separate as some scholarly or canonical accounts claim.' His dismissal of these distinctions reflects how he and others had a less rigid idea of the counterculture; they mixed ideas and fashions that had come to be associated, in those canonical accounts, as denoting separate subcultures. Sebastian, born in London in 1945, recollected more generally about how he perceived the influence of film to have changed his life. ${ }^{x \times v}$ He wrote, 'My life was much less sexy, daring, adventurous, dangerous, changing. The films made me expect more of life.' These accounts offer rather simplistic ways of understanding a change in a life's course due to the messages and images presented in a film or films. The reality was most likely more complex but Joel and Sebastian's words illustrate the power film can wield when being used to summon and organise memories as well as create understandings and retrospective explanations of adolescents learning about life.

While Joel and Sebastian recounted how they had exercised their personal agency, by finding films, to relate to the counterculture, Natalie, a woman born in 1951 in a middle class part of typically industrial and working-class Runcorn, remembered a collective rather than individual experience of discovery that coincided with the changes felt during her own adolescence. ${ }^{\text {xxi }}$ She understood this period of personal discovery and collective learning as shaped by her increasing knowledge of an international counterculture. In a way that was distinctly less elitist than Joel and Sebastian's very individualistic accounts, she recalled how going to socialise at events like dances with a group of friends and how consuming records and clothes, for instance, was significant to her rather than seeing her interest in counterculture as a combination of political, intellectual and/or aesthetic influences. Natalie remembered watching Easy Rider (1969) but she recalls a collective experience when discovering shared ideas and values:

I think it was just - I think we were aspiring to something American - this sort of freedom. I'm growing up in an industrial northern town and in some ways it was still the 50s, it was still very sort of black and white and grey and there was this idea of like 'hey man, I just wanna be free like a bird' [laughs]. And uhm so it kind of, we actually bought, me and quite a few friends, we used to have the soundtrack of the film so we would sit in rooms and listen to it and they... there was a copyright issue, stereo was relatively new, and there's a track on the original Easy Rider (1969) which had the sound of a motorbike going across the speakers, 
and then they realised they hadn't got copyright to take the sound from the film. So then they released it that didn't have the motorbike sound on it all and they re-recorded the motorbike sound and put it on. .xvii

In her account, she transitions from making light of her youthful inexperience to demonstrating how far she has changed since then. In the following remarks, she makes a clear distinction between the artifice of her youth and her transition, through the pursuit of experiences and alternative influences, ones that she perceives as the culture of the time, to become sophisticated:

It was, it was a big sort of cultural icon for us I think. Still bearing in mind I'm still at school... But I mean there were huge changes y'know the May riots in France, meant, in 1968, I mean I was just doing my $O$ levels at that time, and there was students on the streets and all this and we were sort of at school seeing all this happening thinking they're questioning things and so it was part of that sort of culture I think. .xviii

It is clear from the accounts that we gathered that film was not, however, the only way for someone to become interested in or involved with the counterculture. Our participants recount numerous influential factors that guided them towards and interest in or encounters with the counterculture. Danny, from Wolverhampton, who was born in 1950 and understands himself as moving from a working-class childhood to a middle-class adulthood, wrote of his life before attending the University of Sheffield:

Watching TV was a major activity (The Avengers, Danger Man, World Cinema on BBC2); listening to jazz in my bedroom; drinking black coffee with the few friends who shared my burgeoning interest in Existentialism - we saw ourselves as Wolverhampton's 'beats'. ${ }^{x i x}$

Bob, our other man with working class origins in this group and the eldest having been born in 1942, was also enamoured of the beat writers and the 'beatnik' subculture that followed them:

I think at that time, probably slightly before your memory, that the beatniks were the literature point for that sort of thing and I sort of saw myself as a, not quite San Francisco beatnik in Cleckheaton. I just sort of liked alternative things, so I think I saw them a bit as alternative. I had a smattering of French so I could more or less hear what they were saying without the subtitles. Yeah, it was a spin-off the beatnik image. ${ }^{x \times x}$

Danny and Bob's 1960s countercultural interests stemmed from cultural forms that had lineages that reached far into the past. The term 'beatnik' was coined as a pejorative term in 1958. The three most celebrated works of the beats - Allen Ginsberg's Howl, William S. Burroughs's The Naked Lunch and Jack Kerouac's On the Road - were too published in the 1950s long after the cultural experiences that inspired these books had passed by. Similarly, trad jazz was popular in Britain in the 
early 1960s; those playing in the trad jazz style attempted to recover and perform the sounds of American jazz that had been popular during the first three decades of the twentieth century. Consequently, in the above accounts, the 1960 s counterculture is remembered as being inspired by and in dialogue with prior movements and individuals who proposed radical ways of thinking and alternative lifestyles, often through the arts, rather than being ahistorical or entirely novel.

The way our respondents' incorporate encounters with film and other art forms into their life stories during the 1960 s provides evidence of an autodidactic culture - present across class divides as Keith Gildart has noted in regards to working class music fans - in which people made significant efforts at uncovering alternative information through a range of popular and, for that matter, unpopular culture. ${ }^{x \times i}$ In two instances, the encouragement of parents sparked two youths attempts at discovering these alternative messages. Kate, a woman born in 1950 who lived in Birmingham and, from 1964, Liverpool before going to University in London later in the decade, was brought up by an academic mother and professional father. ${ }^{\text {xxxii }}$ They brought her up in a bohemian way ('I had the latch-key around my neck' and 'felt very much an outsider') and introduced her to left politics, art galleries, ballet - 'it was the sort of household where your furniture was collapsing but you were sitting watching a production.' This led Kate to the Everyman - an art centre with a cinema. From this social position and opportunity to consume alternative media in a context individuals and social groups interested in the counterculture met, she perceived changes in film, music, fashion, drugs and attitudes. She recalled, 'there was this sort of rather Bohemian theatre scene through the Everyman and you had all the people like y'know Roger McGough and all these people. These beat poets and stuff like that coming in.' This social context and the media she consumed, a pathway she understands as directly linked to her parents' interests, led her to understand the decade 'completely changing from the bobby socks into the hippies.'

Oscar, like Kate, also includes his parents and childhood inquisitiveness into his account of becoming a participant in the 1960 s counterculture. ${ }^{\text {xxiv }}$ Born in 1950, he lived in south Manchester around the suburbs of Didsbury and Withington until 1967 when he moved into 'hippie squats' in the student area around Burton Road. His childhood cinema going was conventional for someone his age - if perhaps more ardent than others. He recalled with fondness the 'special event, a family event, trip to the pictures' to see films like Lawrence of Arabia (1962) or Spartacus (1960) and trips with his father to see war films which he described as 'some sort of rite of passage thing because he had been in the [Second World] War.' Oscar's formative interest in more esoteric or alternative film and culture was not, however, remembered as being primarily informed by the 1960s counterculture, underground or hippie culture. He recalls several prior interests that led him to discover new ideas and provided him with concepts and a lexicon to make sense of what he would find. As he puts it he was 'crazy about silent movies' thanks to a late night television show on BBC2 called Silents are Golden that aired 30-minute-long edited versions of Birth of a Nation (1915) or Ben Hur (1925). Remembering Silents are Golden provoked and earlier, similar memory. He recalled this was where he would watch films from the French New Wave by innovative and provocative directors like François Truffaut and Jean-Luc Godard,

The Ashes and Diamonds trilogy on BBC One in like 1965 and they put on a short season of foreign films, so I was seeing Shoot the Pianist (1960 [or Shoot the Piano Player as it was entitled for US audiences) or whatever. They'd go, here is some film by a Frenchman who has some jolly silly ideas about movies however make your own minds up, we are now going to show you a Jean-Luc Godard film. ${ }^{\text {xxv }}$ 
His parents bought him books about film bought for birthdays and Christmases and he lived nearby to Paul Rotha, the documentary filmmaker, author and critic, who would lend him books. Film writing and criticism in the post-war period was brimmed with debate about avant-garde ideas and politics, Oscar was privy to this at a rather young age through his parents and the specific middleclass locality that offered him social connections with people like Rotha.

When being asked about cinema-going and memories of films during the 1960s by an interviewer, it is unsurprising that these predominantly middle-class participants recount a picturesque image of films and culture having a great determinant effect on their lives and memories. They tend to consider profound structural and material factors that shape the course of lives, understandings and memories less: they, predominantly, stress their personal decisions and intellectual curiosity. Class was a significant factor in how people accessed certain subcultures: the vast majority of those in our sample were privileged to be able to choose identities (or at least tell themselves that they did) and social mores. Bob, who grew up working class, explained who he was a beneficiary of post-war social mobility due to a good result in his 11-plus test (the examination which was used to split young people into either more 'academic' grammar school education or more vocational secondary modern schooling).

Comparing the subcultural life remembered by one of our working class respondents, who insists that she remained working class throughout her life, to the middle-class respondents illustrates a way of understanding journeys into subcultures that held different class connotations. Laura, from Bolton in the north west of England, was a teenager and young adult during the 1960s and saw herself as part of a 'rocker' subculture. ${ }^{\text {xxxi }}$ The cinema was an important space for her transition from childhood to adulthood: like so many of our participants, it was at the cinema where she went on her first date with her future husband at 18. It was also a place for her to misbehave and perform her subcultural affiliation as a 'rocker': for instance, along with her friends, she was briefly banned for being 'noisy'. Films that were countercultural, and particularly those that represented drug-taking and drug culture, alienated and troubled her. When asked her general recollections of the 1960s, Laura wrote:

Midnight Cowboy (1969) ... and the psychedelic party. It still makes me feel queasy to watch that scene. All the people (except Dustin Hoffman's character) are out of mental control, which would have bothered me, even to watch it. Neither myself, or my friends, ever dabbled in drugs. We knew that they were 'around' but never would have considered trying them.

Drugs were associated, in my world, with students and 'mods'. The 'rocker' fraternity would have been more interested in beer and cigarettes.

More importantly, we had to get up each day to go to work and couldn't be 'hung over' either with drugs or drink. We started work at 15 or 16 years old, and when we met our future husbands, which was often at 18 years old or so, we would start to save up for a house (ownership rather than renting) and marriage. This was the life of the working class teenager. ${ }^{\text {xxxvii }}$ 
She added that she had 'no idea that alternatives [to her lifestyle] were out there, and even if I had have known I would have felt too inferior to attend anything that wasn't "working class".' There were northern working class subcultures of the time within which amphetamine use was common; the Twisted Wheel club, only a few miles from Laura, was a hub of amphetamine use as people danced to soul music. Laura, and many others from a similar background, however, claim to be put off by the idea of drugs and, particularly, the consciousness-altering drugs like L.S.D. that were associated with the counterculture. Laura narrates 'dropping out', temporary or permanent 'insanity' as incompatible with her everyday life and community ties.

Being middle class or the socially mobile working class gave our countercultural interviewees opportunities to move into spaces where they could access alternative lifestyles and ideas. There are regular patterns in their education backgrounds, for instance. They typically attended liberal or arts institutions where, in their responses to our survey, they explain how they felt free to explore extracurricular interests meet likeminded people and develop or visit places that hosted alternative culture such as university film societies. Danny attended the University of Sheffield where, according to his account, most of his learning was distinctly extra-curricular and under the influence of cannabis. Joel attended Art College having been inspired by Blow Up! (1966) Natalie moved to London to go to Art College and Kate moved to London to attend the New College of Speech and Drama to study music. She explained that this was to gain 'independence.' Oscar's education was unique compared to the others and had a particular significance to his formative identity, he recalled being selected at the age of 11 to attend Manchester High School for the Arts:

Oscar: There were, there were guidelines and vague discipline but it was always reliant on your own moral thinking - you shouldn't do this because it will upset other people. There was no punishment and we were encouraged. I was trained to be a sculptor. So that was what I was destined to be supposedly. So I got training in printing, from wood cut to offset litho, trained in all forms of sculpture, casting, pottery, and in draftmanship skills drawing life, still life etcetera etcetera so I was destined for art school.

Interviewer: And you went to art school?

Oscar: No I dropped out. At 17 just to be a musician. I lived by being a musician... I went very odd at 14, I became an atheist and adopted certain political stances which remain to this day. I am, at heart, an Anarcho-Syndicalist and I believe violently in anti-religion. However, yeah, yeah, so after 14, I wouldn't do anything that anybody was telling me to do, even at school, even if people were being very nice to me, I would be like how dare you! ${ }^{\text {xxxviii }}$

Oscar explains how his countercultural affiliation was the culmination of his artistic interests, and indeed skill, along with his independence of thought and rebelliousness. In his account, he presents his movement into countercultural milieu and ideas as a gradual process of situated learning rather than a single moment of change or an adventurous move from to a place or city (perhaps in some part due to Manchester's local countercultural scene). It is also clear that the political and philosophical views that he articulated were formed in dialogue with earlier radical traditions - art education, liberal and radical teaching methods, and Anarcho-Syndicalism - and, as suggested in his interview, this remained an important aspect of his self-identity to the present. 


\section{Visiting the cinema}

Both improvised temporary places to view films and conventional full-time cinemas were one of several places where those interested in or involved in the counterculture could socialise, while receiving and interpreting messages from media associated within the counterculture. In some cases, certain screening times (late night) and showings of genre films, such as horror, came to be associated with types of countercultural sociability as well. This group of cinema-goers did, however, visit the cinema in ways similar to wider society, Kate remembers the cinema as having particular importance to her because 'you could not afford to go to a theatre, or a concert or anything like that in London.' Joel recalled that he still enjoyed visiting Odeon chain cinemas 'for their art deco appearance.' By hosting late night showings of horror films and lax enforcement of behaviour within the cinema, nationwide cinema chains had happened on a way of attracting young thrill-seekers into the cinema even more than usual. Oscar recalled that the Odeon on Oxford Road in Manchester would sometimes show horror films on Saturday nights at midnight to audiences of around 200 in an auditorium that could seat about 2,000. He remembers the crowds being 'quite quiet' because they were 'absolutely stoned' due to the fug of cigarette smoke cinema-goers could 'sneak a joint in. Acid would be taken before hand which would always make the horror films interesting.' He remembered the cinema staff being quite accommodating because the showings boosted their income and because '[late night cinema-goers] didn't cause much trouble because all the drunks would be off to clubs fighting and we'd want to sit down for three hours and watch movies. It was good for the freaks.' On the other side of the Peak District, Danny and his 'hippie' friends in Sheffield, after eating a curry, drinking in the student union and smoking 'marihuana', 'went to late night horror film screenings in the city centre - we would walk back at night after the buses had stopped rather "stoned" - Sheffield would look quite magical!"

The respondents involved in counterculture were, however, slightly more likely than typical respondents to our survey to visit independent or arthouse cinemas. These cinema-goers conforms most closely to the notion that those interested in the counterculture were elitist and perhaps even a little pretentious. Some openly discuss the benefits of quiet cinemas frequented by middle-class people. Sebastian went to see films in 'middle class areas where they would shut up and watch the film', he watched foreign cinema because to him it offered 'better, more interesting, exciting films and the norm for my circle.' He provided a verbal map of these cinemas in London:

Paris Pullman, small, unkempt, bad sound; Eurofilms Academy Cinema, Oxford Street, art films; West end, smart underground cinema in Tottenham Court road, Pierrot le Fou etcetera; famous art cinema in Hampstead, another in Haverstock Hill, two in Notting Hill, one in Golders green and the rest! $!^{\mathrm{xxxix}}$

Joel recalled visiting independent cinemas such as the Academy in Oxford Street and the National Film Theatre (a cinema run by the British Film Institute). Bob told an interviewer,

'I grew up knowing only the big chains, but as the 1960s wore on I became a habitue of independent cinemas and made special trips to London to see important films at venues like 
the Curzon - the modern simplicity of such cinemas seemed appropriate for films that demanded your full engagement - Persona (1966) would have seemed incongruous. ${ }^{x \mid}$

In his account, the spatial transition from the ornate, perhaps symbolically superficial and garish, 'low culture' to a streamlined 'highbrow' alternative is used to denote sophistication, knowingness and difference from mass culture and society. Bob's hints at a degree of discomfort in his move from working class origins through grammar school, university and into a job in academia; he passed from the culture that he was originally accustomed to something that he has come to consider as more worthwhile. Like Richard Hoggart's 'scholarship boy', his account hints at how he adopted negative preconceptions about working class life. ${ }^{\text {xli }}$

Bob might have been alienated from his origins, but seems to have found smaller communities based on shared interest in film, music and literature with their own spaces to gather and interact with aspects of the counterculture. He wrote at length about his visits, during the later 1960s, to the students film club at Twickenham College of Technology in south west London. Around 30 people per week, he claimed, would attend film screenings but he still kept his apparent distance, 'it wasn't a club in as much as you joined, you just "oh good film this week, l'll go.' Many others who responded to our survey mentioned students film clubs, but it seems that they formed particular significance for our countercultural group. They were a little more social than Bob. Kate remembered visiting the film society which was,

In the basement at college and we always went to that. Can't remember what we want to see, but there'd be quite a lot of arty films and foreign films, whole spread of stuff because the college I was in's specialist subjects were music and drama so you know it was an obvious place ... that was good fun because you met a lot of like-minded people who were interested

$\cdots$

Of the main college it was down in the basement which is where we had all the student led stuff, you know we had a coffee bar down there and.... can remember sitting in that coffee bar listening to 'Ground Control to Major Tom'. That was my era. Yes so it was down there so it must have been, it would have just been rigged up in the coffee bar or something like that. ${ }^{\text {xlii }}$

Danny recalled,

I became interested in avant garde films and would see them in Art college settings and rooms improvised for screenings, even projected in homes on Super 8 equipment ... After screenings of serious films at the university Film society we would often go to someone's room to discuss the film, drink tea and smoke marihuana. ${ }^{\text {xliii }}$

Oscar remembered how university film societies were linked through Contemporary Films, a distribution company based in Brighton that had an archive of left wing, avant garde and 
independent films from the dawn of cinema onwards. He also recalled how non-students and the growing number of Arts Labs became intertwined which created a network of countercultural people and local institutions:

Oscar: because all the social secretaries were incredibly corrupt in as much as they were all dope-smokers and acid heads, we'd all, even though I wasn't at university, we'd all look through the catalogue and say, ooh wow we've never seen Chupacabra, or, ooh look, you can get Chelsea Girls but we'll need two projectors.

Interviewer: Yeah.

Oscar: And so from about '67 onwards we were getting hold of any film - like Häxan ... I saw that in ' 67 with the William Burroughs voiceover which I think Contemporary put out. [Impersonating William Burroughs's voice] 'And then he kissed the Devil's ass'. So happy days....

By mentioning Contemporary Films, Oscar, again, hinted towards the histories, social formations and ideas that were drawn upon by the 1960s counterculture. The film distribution company had been founded in 1951 by Charles Cooper, an English Communist who had emigrated to the US in the 1930s but had returned due to the McCarthy witch-hunt. ${ }^{x l v}$ Cooper had been a member of the British Kino and the Film and Photo League during the 1930s, collected 'classics', including Soviet and American labour films such as Salt of the Earth (1945), and, on his return to Britain, continued to collect and distribute radical, avant-garde and international cinema. When remembering the Manchester Arts Lab, he recalled how Oscar and his local scene recreated aspects of London's counterculture locally and interacted with the capital:

We opened one in Manchester, I think, in 1967 in the basement of a club and they let us use it on Tuesdays or Sundays or something like that and we'd just go to London on the coach and go to Wardour Street or wherever to see what we could blag and we got a copy of Magical Mystery Tour (1967) and brought that back and played it ... we did a short season of Cuban revolutionary films. ${ }^{x \mid v i}$

The Cuban revolutionary films were almost certainly from Contemporary Film's collection. Oscar's memory of visiting Wardour Street in Soho, the hub of the film industry, and just fifteen minutes walk from the Arts Lab in Drury Lane, show how the counterculture both drew from discourses and images from prior alternative or radical histories and developed spaces that interacted with the countercultural hubs in London or tried to recreate them.

\section{Interpreting Films}

The films recalled by participants, the reasons why they recalled them and their opinion of these films are often tied up in their personal impressions and interpretations of the 1960s. The films are 
frequently taken as representing or misrepresenting aspects of the $1960 \mathrm{~s}$ - at least of their 1960s and interpreted through frames of reference that the narrator understood to be of that time.

Arguably, as films were not watched and re-watched at home to the taken-for-granted extent that they are now (albeit some people had small $16 \mathrm{~mm}$ projectors), they occupy a particular place in the memories of avid cinema-goers. Oscar explained how the rarity of underground film leant a particular urgency to how he remembered:

Well, you didn't have a [VCR]. I've said this about going to see gigs in those days: we had a fairly sophisticated data storage and retrieval system in our heads where you burnt these films and these gigs into our minds. My wife can't believe that I have quite an astonishing recall of films. If there's a TV programme, a TV in the living room and a film on, l'll go, oh it's Bridge Over the Rive Kwai (1952) and know it all. And I've just told her that it is left hand and right hand brain, I just remember different things to what she remembers. That idea of you'll never see it again so it has to live on in here was very important, particularly with things like Chelsea Girls (1966) and a lot of the underground films. You're never going to see them on TV, they were beyond the pale so far as society and civilization are concerned therefore you must commit them to memory. .lvii

Films endure in people's memories in ways often more idiosyncratic and less clear than Oscar claims his memories and recall to be. From the 1980s, with the introduction of the VCR, films were more easily available to watch in the home which adds a degree of difficulty when considering how they are woven into personal and general narratives of the 1960s. These memories and understandings of films, despite a degree of trickiness encountered when analysing them, do, however, provide a way into understanding how interactions with the counterculture are perceived today to have shaped people's reception of films, themselves and the decade.

The counterculture is frequently said to have challenged the way in which people perceived reality and consciousness. Consciousness-altering drugs, anti-psychiatry, postmodernism, psychedelia and alternative spirituality, for instance, provided means to challenge the conventionally accepted basis of the real, opening it up to relativism and a plurality of realities, or, in some cases, offer the possibility of a seemingly more authentic reality. Our participants understood film - despite being artificial and, at best, resembling a reality rather than simply capturing it - to have confirmed aspects of their own 'reality', questioned reality and offered versions of other realities. Dorian said that the British new wave's social realism or 'kitchen sink' drama, 'opened my eyes to a reality I hadn't been aware of and reinforced my liberal principles. ${ }^{\text {,xviii }}$ He added, 'I identified with the view "our stories have a right to be told and told in an "up yours" way. Plus I was a hippy.' His countercultural affiliation shaped his view of the films, despite the people depicted in the films being of another class. He also empathised with the indignities of the British class system due to the discrimination he suffered as a gay man, he explained, 'a middle class upbringing meant l'd been sheltered from the real world that was depicted so graphically in 60s films. Being gay, however, allowed me to value the sense of being an outsider that was mirrored in many of the films.'

Oscar, growing up near working-class areas in the north, only a few miles from Lower Broughton in Salford where Shelagh Delaney had been born and written the play A Taste of Honey which had been turned into a hit film in 1960, had a slightly different take on this brand of realism. 
He remembers seeking something else from films beyond politically significant and revealing representation:

Oscar: Respondent: Well, I was having that rammed down my throat at school and I hated the whole social realist movement. ... Cinema became more hippie and more vital because we were now getting messages from - that sounds like passive paranoia - from like Easy Rider (1969) and that's very early '70s isn't it?

Interviewer: No, '69.

Oscar: Which I loathed, I loathed it but freaks had made it and they were our people, you knew that you weren't on your own. There were the messages that you were getting.

Kate and Danny remembered the film Blow Up! (1966) as being a reflection of the 'real' 1960s, but their countercultural affiliation seems to have waned as they grew older unlike Oscar who has continued to be involved in underground film, music and arts. These different patterns of personal development have a bearing on how they narrate their memories. When considering Blow Up! (1966) Kate has moved on from the idea that the messages learnt in the counterculture provide a relevant way of understanding film, 'Yes I would say it did [reflect 'swinging London'] a bit. In its own way. In a.... I was going to say arty which sounds a bit weird today because if you looked at it today you wouldn't see it that way but then you did.' Danny understands the cinema of the time as an accurate reflection of the reality he experienced, but this perspective was rather nostalgic:

A society is complex, and the 60s were a complex time - one's experience depended on class, gender, 'race', what part of the country you lived in, your age. I was one of the working class kids who got to University as the Sixties were shifting in mood from 'swinging' to 'angry'. It was confusing. Drugs played a major role for many young people at the time. Sexual mores were shifting. Film censorship was relaxing. But war in Vietnam cast a dark shadow. Many cinemas were becoming shabby and closing as the decade ended. Hollywood seemed exhausted, retrograde - which was why Easy Rider (1969) was such a hit with younger people. 60 s films reflected the times. When I watch the films today some make me feel how the '60s dream' was to go unfulfilled. I think Blow Up! (1966) can be read as a warning. ${ }^{\text {xlix }}$

Danny made a telling distinction, however: he described films such as Smashing Time (1967), a socalled 'swinging London' film as seeming 'exploitative to me' because 'my friends were 'sixties radicals' and very angry at how 'society' was appropriating radical ideas and images for commercial purposes." His comment calls attention to his perception and memory of authentic forms of culture and social change that he considered distinct from commercial representations of counterculture. His notion of authenticity also informed his ideas about celebrity. He commented: 'the notion of "film star" seemed increasingly antiquated at the time. Che Guevara was a "star". The films I respected were not "star vehicles".' Bob rather than seeking representations of political radicalism and social change was searching for an authentic 'cool', speaking about Last Year At Marianbad (1961) explained, 'I don't know why I liked it. It was... we had a phrase at the time which used to be 
suitably detached, so if you were cool you were suitably detached and it...the whole ethos of the film struck me as suitably detached."li

Others involved in the counterculture interpreted films through the prism of other new perspectives that had increased in popular prominence during the decade. The two women in our sample remembered how they associated films of the 1960s with the feminist politics that they had begun to be aware of and engage with during the decade. Natalie remembers discussing feminism with friends at school when studying for her A Level in English and reading feminist texts. She saw strong female characters in films as examples of different sorts of empowered femininity:

[Being] From a middle class background I was supposed to get myself a rich husband, and then be a housewife and it was kind of realising that this wasn't the game plan for my brother that made me realise there was a double-standard and so images of women who were some way in control and independent were appealing to me certainly so, we've got Faye Dunaway ... Marlene Dietrich and Mrs Robinson. ${ }^{\text {lii }}$

Kate saw the Holly Golightly character played by Audrey Hepburn in Breakfast at Tiffany's (1961) in a similar light. She drew parallels with her life as a young woman gaining her independence: 'it all felt terribly as though we were entering the wider world and it was a change of scene. ${ }^{\text {liii }}$ Characters embodied and represented ideas of feminism in our respondents' memories that endured, but feminism also informed Natalie's critique of 1960s films with reductive views of women, sexist themes and characters. She reminisced:

Certainly with Alfie (1966) I was disturbed I think, and I think - there were a couple where I started - there were these sort of glimmerings of these feelings forming... that this wasn't right and I wasn't comfortable with it. Because there was - the feeling was that you were the alternative seemed to be 50s housewife or dolly bird - so dolly bird seemed freer, and then you realised that this was also still quite restrictive and you were still being an image and a sex-object but I think it was only glimmerings of feeling uncomfortable. I mean I look at it now and think 'That's terrible!' and yet at the time it was 'oh what a lad!' - it was much more that sort of thing. 'Oh Alfie, you are a one' sort of thing, rather than 'that's an appalling attitude to women! !iv

\section{Conclusion}

My prior article failed to fully explore how these people, who identified with the counterculture imagined themselves and how cinema and cinema-going informed their identities and understandings of life. Affiliation to the counterculture and engagement with alternative ideas had a profound effect on this particular group of people. Unsurprisingly bearing in mind the focus of the research project, the counterculture clearly informed how they understood and remembered film. The two women involved in the counterculture, for instance, viewed films through the lens of their developing knowledge and the societal conversation about feminism and gender roles. Films like Blow Up! (1966) and Easy Rider (1969) are remembered by almost all of this group as 
representative of the times and providing messages and inspiration that were carried into the respondents lives. This suggests the resilience of films seen at the cinema in memories, despite their slipperiness when people try to recall specifics as Burgin has argued, and how they can be used in narratives as shorthand to explain individual's lives, denote turning points, acts as a way to recall and interpret certain ideas, and epitomise their impressions of the time that they lived in.

This article has also shown that the interviewees and questionnaire respondents to the 1960s British cinema-going survey that were involved in the counterculture's memories complicate canonical accounts of the counterculture. One of the most striking distinctions between these perspectives is how our participants described the counterculture, hippies and 'Swinging London' as being part of the same social, cultural and intellectual movements. The account differs from people who were at the epicentre of the counterculture who often consider those labels to denote separate subcultures or scenes. This broader notion of the 1960s counterculture in Britain, on the other hand, gave a space to explore the associated ideas, films, fashions and other arts and media proved significant to how our respondents understood themselves and the decade in general. For instance, their engagement with the counterculture seems to have inspired them to remember, and cherish memories, of artistic expression, expect personal freedoms and either visit or instigate alternative public spaces. As well as understanding themselves to be part of a subculture that was of its time, they recall and understand the counterculture as building on prior intellectual and cultural movements. Nonetheless, London's importance to the respondents - reflected in the number of participants who moved there, visited or emulated developments such as the Arts Lab - shows that the capital retained an allure and significance that formed part of understandings and memories of the counterculture. This article shows there is a bigger picture to explore, however, when understanding the scenes that, while perhaps small in terms of the number of people involved, had a disproportionate effect on popular cultural and historical understandings of the decade.

The article also demonstrates that, despite those historians that claim a 'cultural revolution', long-established ties of class and gender remained highly significant factors in how people lived their lives and whether they had access to or felt comfortable living alternative lifestyles. Many of our participants were encouraged by middle-class parents to take an interest in film and the arts, socialised with others who had similar interests and had a degree of freedom to experiment, with drugs for instance, that were different to their working class counterparts. The two respondents who were born into working class families had specific educational opportunities - grammar school and university - that allowed them to pass into the middle class counterculture more easily. Art College and university were an important space for some of our participants to become involved in the counterculture and, frequently, through film clubs and societies. This social grounding provided a context to find and understand film, media and arts that provided inspiration and proved influential in their memories and, arguably, their lives at the time.

\footnotetext{
'Interview with Oscar, CMBCG, UCL, transcript number 0964.

ii Glen, 'Exploiting the Daydreams.'

iii Kuhn, An Everyday Magic.

iv Interview with Mervyn, CMBCG, UCL, transcript number 0014.

"Burgin, The Remembered Film, 50-1.

vi Foucault, "Of Other Spaces."

vii Grossberg, We Gotta Get Out, 83-84.

viii Bourdieu, Distinction, 1-2.

${ }^{\text {ix } G r e e n, ~ A l l ~ D r e s s e d ~ U p, ~ x i . ~}$
} 
${ }^{x}$ Booker, The Neopheliacs. Farren, Give the Anarchist. Melly, Revolt into Style. Taylor, Twenty Years Ago Today. Miles, In the Sixties.

xi Campbell, “Accounting for the Counterculture", 110-111.

xii Gemie and Ireland, "The Consul and the Beatnik", 463.

xiii Bingham, Family Newspapers? 121. See also Thomas, "Challenging the Myths."

xiv Donnelly, Sixties Britain, 124.

xv August, "Gender and 1960s Youth Culture". Brunt, "An Immense Verbosity". Campbell, "A Feminist Sexual Politics". Jeffreys, Anticlimax. Jeffries, Anticlimax. Rowbotham, In Place of a Dream.

${ }^{x v i}$ Foucault, The History of Sexuality, 7-8.

xvii Gildart, Images of England. Hall and Jefferson, Resistance through Rituals.

xviii Maltby, Biltereyst and Meers, Explorations in New Cinema History, 9.

${ }^{\mathrm{xix}}$ Kuhn, An Everyday Magic. Smith, A Riot at the Palace. Puwar, 'Social Cinema Scenes.' Stokes and Jones, 'Windows on the World.' Jones, 'Far from Swinging London.' Pett and Stokes, 'Cinema Space and Postcolonial Audiences.'

${ }^{x x}$ Ibid.

${ }^{x x i}$ Sutcliffe-Braithwaite, 'New perspectives from unstructured interviews.'

xxii Ibid., 2.

xxiii Kuhn, An Everyday Magic, 5-7.

xxiv Questionnaire by Joel, CMBCG, UCL, transcript number 0096. Our project was conducted on the basis of complete anonymity; pseudonyms only are used here.

${ }^{x x v}$ Questionnaire by Sebastian, CMBCG, UCL, transcript number 0046.

xxvi Interview with Nathalie, CMBCG, UCL, transcript number 0759.

xxvii Ibid.

xxviii Ibid.

xxix Questionnaire by Danny, CMBCG, UCL, transcript number 0424.

${ }^{\mathrm{x} x \mathrm{x}}$ Interview with Bob, CMBCG, UCL, transcript number 0704.

${ }^{x \times x i}$ Gildart, Images of England, 9-10.

xxxii Interview with Kate, CMBCG, UCL, transcript number 0775.

xxxiii Ibid.

xxxiv Interview with Oscar.

$x x x v$ Ibid.

xxxvi Interview with Laura, CMBCG, UCL, transcript number 0249.

xxxvii Ibid.

xxxviii Interview with Oscar.

xxxix Interview with Sebastian.

${ }^{x l}$ Interview with Bob.

xli Hoggart, Uses of Literacy, 238-39.

xlii Interview with Kate.

xliii Interview with Danny.

xliv Interview with Oscar.

${ }^{x l v}$ Hogenkamp, Film, Television and the Left, 8.

xlvi Interview with Oscar.

xlvii Ibid.

xlviii Questionnaire by Dorian, CMBCG, UCL, transcript number 0707.

xlix Interview with Danny.

I Ibid.

li Interview with Bob.

lii Interview with Nathalie.

liii Interview with Kate.

liv Interview with Nathalie.

\section{Bibliography}


August, Andrew. "Gender and 1960s Youth Culture: The Rolling Stones and the New Woman." Contemporary British History 23, no. 1 (2009): 79-100.

Bingham, Adrian. Family Newspapers?: Sex, Private Life, and the British Popular Press 19181978. Oxford: Oxford University Press, 2009.

Booker, Christopher. The Neophiliacs: Revolution in English Life in the Fifties and Sixties. London: Pimlico, 1992.

Bourdieu, Pierre. Distinction: A Social Critique of the Judgement of Taste. Cambridge, MA: Harvard University Press, 1984.

Brunt, Rosalind. "An Immense Verbosity: Permissive Sexual Advice in the 1970s" in Feminism, Culture and Politics edited by Rosalind Brunt and Caroline Rowan. London: Lawrence \& Wishart, 1982: 143-170.

Burgin, Victor. The Remembered Film. London: Reaktion Books, 2004.

Campbell, Beatrix. 'A Feminist Sexual Politics: Now You See It, Now You Don't,' Feminist Review 5 (1980): 1-18.

Campbell, Colin. "Beatniks, Moral Crusaders, Delinquent Teenagers and Hippies: Accounting for the Counterculture" in The Permissive Society and Its Enemies edited by Marcus Collins. London: Rivers Oram Press, 2007: 110-111.

Farren, Mick. Give the Anarchist a Cigarette. London: Pimlico, 2001.

Foucault, Michel. The History of Sexuality Volume One: An Introduction. (New York, NY: Pantheon, 1978.

Foucault, Michel. "Of Other Spaces." Architecture/Mouvement/Continuité no. October (1984). Translated from the French by Jay Miskowiec.

Gemie, Sharif and Brian Ireland. "The Consul and the Beatnik: The Establishment, Youth Culture and the Beginnings of the Hippy Trail (1966-8)." Twentieth Century British History, 28, no. 3 (2017): 440-464.

Glen, Patrick. 'Exploiting the Daydreams of Teenagers,' Media History (2017), DOI: 10.1080/13688804.2017.1367653.

Green, Jonathan. All Dressed Up the Sixties and the Counterculture. London: Pimlico, 1998.

Lawrence Grossberg, We Gotta Get Out of this Place: Popular Conservatism and Popular Culture (New York, NY: Psychology Press, 1992).

Hall, Stuart and Tony Jefferson, Resistance through Rituals: Youth Subcultures in 
Post-war Britain. London: Routledge, 1996).

Hoggart, Richard. The Uses of Literacy Aspects of Working-class Life. London: Penguin, 1957.

Hogenkamp, Bert. Film, Television and the Left, 1950-1970. London: Lawrence \& Wishart, 2000.

Jeffreys, Shelia. Anticlimax: A Feminist Perspective on the Cultural Revolution. New York, NY: New York University Press, 1990.

Jones, Matthew. 'Far from Swinging London : Memories of Non-urban Cinema-going in 1960s Britain.' In Cinema Beyond the City: Small-Town and Rural Film Culture in Europe edited by Judith Thissen and Clemens Zimmerman. London: BFI, 2017, 117-129.

Kuhn, Annette. An Everyday Magic: Cinema and Cultural History. London: I.B. Tauris, 2002.

Maltby, Richard, Melvyn Stokes and Robert Clyde Allen. Going to the Movies: Hollywood and the Social Experience of Cinema. Exeter, University of Exeter Press, 2007.

Maltby, Richard, Daniel Biltereyst and Phillipe Meers. Explorations in New Cinema History: Approaches and Case Studies. Chichester: Wikey-Blackwell, 2011.

Marwick, Arthur. British Society Since 1945. London: Penguin, 2003.

Marwick, The Sixties: Social and Cultural Transformation in Britain, France, Italy and the United States. London: Bloomsbury, 2011.

Melly, George. Revolt into Style: The Pop Arts in Britain. London: Allen Lane, 1970.

Miles, Barry. In the Sixties. London: Pimlico, 2003.

Pett, Emma, and Stokes. 'Cinema Space and Postcolonial Audiences in 1960s Britain.' In Kinoerfahrungen: Theorien, Geschichte, Perspektiven edited by Florian Mundhenke and Tomas Weber. Hanburg: Avinus, 2017.

Puwar, Nirmal. 'Social Cinema Scenes.' Space and Culture, 10, no. 2 (2007): 253-270. https://doi.org/10.1177/1206331206298788

Stokes, Melvyn and Matthew Jones. 'Windows on the World: Memories of European Cinemas in 1960s Britain.' Memory Studies 10, no. 1 (2017): 78-90.

Stokes, Melvyn and Richard Maltby. Identifying Hollywood's Audiences: Cultural Identity and the Movies. London: British Film Institute, 1999.

Smith, Sarah J. 'A Riot at the Palace: Children's Cinema-going in 1930s Britain.' Journal of British Cinema and Television 2, no. 2 (2008): 275-289. 
Sutcliffe-Braithwaite, Florence. 'New perspectives from unstructured interviews: young women, gender and sexuality on the Isle of Sheppey in 1980.' SAGE Open (2016).

doi:10.1177/2158244016679474

Taylor, Derek. It was Twenty Years Ago Today. London: Fireside, 1987.

Thomas, Nick. "Challenging the Myths of the 1960s: The Case of Student Protest in Britain."

Twentieth Century British History 13, no. 3 (2002): 277-297. 